\title{
Speech Recognition Untuk Aplikasi Kamus Bahasa Indonesia-Sumbawa Berbasis Android
}

\author{
Muhammad $^{1}$, Syahroni Hidayat ${ }^{2}$, Ahmad Zuli Amrullah ${ }^{3}$ \\ ${ }^{1}$ Universitas Bumigora, tkjmuhammad@gmail.com \\ ${ }^{2}$ Universitas Bumigora, syahroni.hidayat@stmikbumigora.ac.id \\ ${ }^{3}$ Universitas Bumigora, zuli@ universitasbumigora.ac.id
}

\begin{abstract}
ABSTRAK
Sumbawa sebagai salah satu daerah yang dianugrahi potensi wisata yang beragam menjadikan daya tarik masyarakat luar Sumbawa (wisatawan) untuk berkunjung, bekerja, maupun untuk belajar. Namun terkadang bahasa menjadi salah satu kendala yang dihadapi mayarakat luar Sumbawa jika ingin berinteraksi dengan masyarakat asli Sumbawa. Sehingga dibutuhkan sebuah instrument yang bisa digunakan sehingga perbedaan bahasa tidak menjadi kendala dalam berinteraksi yaitu kamus. Oleh karena itu, kamus yang disajikan haruslah sesuai dengan teknologi yang banyak diminati oleh masyarakat Indonesia pada umumnya yaitu smartphone Android dikarenakan fitur-fitur yang tersedia dalam smartphone tersebut. Salah satu fiturnya adalah speech recognition.Perancangan sistem ini dilakukan dengan metodologi waterfall yang terdiri dari proses analisis, desain, pengkodean, pengujian, dan terakhir pemeliharaan. Tools yang digunakan adalah Android Studio dan DB Browser for SQLite (DB4S). Metode pengujian menggunakan Black Box untuk uji fungsionalitas aplikasi dan Word Correct Rate (WCR) untuk menguji akurasi sistem dengan menggunakan 30 kata yang berbeda dan setiap kata diulang sebanyak 10 kali. Hasil yang sudah dicapai dalam penelitian ini adalah terciptanya aplikasi Kamus Bahasa Indonesia- Sumbawa Berbasis Android dengan memanfaatkan teknologi speech recognition.Kesimpulan dari penelitian ini adalah Uji fungsionalitas menunjukkan fitur-fitur aplikasi dapat bekerja dengan baik ketika offline maupun online. Sedangkan untuk uji coba akurasi sistem didapatkan hasil WCR secara berturut-turut sebesar 92.67\% ketika offline dan 95.33\% ketika online.
\end{abstract}

Kata Kunci : Bahasa Sumbawa, Speech Recognition, Android, Word Correct Rate (WCR).

\begin{abstract}
Sumbawa as one of the areas that is blessed with diverse tourism potential makes the appeal of people outside Sumbawa (tourists) to visit, work, or to study. But sometimes language becomes one of the obstacles faced by people outside Sumbawa if they want to interact with the native people of Sumbawa. So we need an instrument that can be used so that differences in language do not become obstacles in interacting with the dictionary. Therefore, the dictionary presented must be in accordance with the technology that is in great demand by the Indonesian people in general, namely Android smartphones because of the features available in these smartphones. One of the features is speech recognition. The design of this system is done by the waterfall methodology which consists of the process of analysis, design, coding, testing, and finally maintenance. The tools used are Android Studio and DB Browser for SQLite (DB4S). The testing method uses Black Box to test application functionality and Word Correct Rate (WCR) to test the accuracy of the system using 30 different words and each word is repeated 10 times. The results achieved in this study are the creation of an Indonesian-Sumbawa-based Dictionary application Android by utilizing speech recognition technology. The conclusion of this research is the functionality test shows that the application features can work well when offline or online. Whereas for testing the accuracy of the system the WCR results obtained were 92.67\% when offline and $95.33 \%$ when online.
\end{abstract}

Keyword: Sumbawa, Speech Recognition, Android, Word Correct Rate (WCR).

\section{PENDAHULUAN}

Indonesia merupakan negara kepulauan yang memiliki suku bangsa, budaya, dan Bahasa daerah yang beragam dimana setiap bahasa menjadi sarana komunikasi yang sangat penting dalam melakukan interaksi. Salah satu bahasa daerah yang dimaksud adalah bahasa daerah Sumbawa.

Bahasa Sumbawa adalah bahasa yang dipakai oleh masyarakat asli Sumbawa atau masyarakat luar Sumbawa untuk dapat berinteraksi. Bahasa Sumbawa masuk dalam kategori Sunda dari Bahasa Melayu-Polinesia Barat, famili Austronesia. Ada empat dialek yang umum digunakan oleh masyarakat Sumbawa yaitu dialek Samawa, Taliwang, Jereweh, dan Tongo [12].

Sumbawa sebagai salah satu daerah di Indonesia terletak di Provinsi Nusa Tenggara Barat (NTB) yang terbentang dibagian selatan kepulauan nusantara. Sumbawa sebagai salah 
satu daerah yang dianugrahi potensi wisata yang beragam dapat menjadi daya tarik masyarakat luar Sumbawa (wisatawan) untuk berkunjung, bekerja, maupun untuk belajar. Namun terkadang bahasa menjadi salah satu kendala yang dihadapi mayarakat luar Sumbawa jika ingin berinteraksi dengan masyarakat asli Sumbawa [20].

Suatu instrument (alat) penerjemah kosa kata diperlukan untuk dapat berinteraksi dan memahami bahasa yang digunakan pada setiap daerah. Kamus adalah salah satu instrument yang bisa digunakan sehingga perbedaan bahasa tidak menjadi kendala dalam berinteraksi [20]. Oleh karena itu, kamus yang disajikan haruslah sesuai dengan teknologi yang banyak diminati oleh masyarakat Indonesia pada umumnya. Salah satu teknologi yang dimaksud adalah smartphone.

Dewasa ini, Android merupakan smartphone yang paling banyak penggunanya di dunia, salah satunya negara Indonesia dikarenakan fitur-fitur yang tersedia dalam smartphone ini dapat memuaskan kebutuhan para konsumen. Salah satu fiturnya adalah speech recognition. speech recognition atau speech to text banyak digunakan untuk memudahkan jika seseorang tidak ingin menginput mengunakan keyboard dalam aplikasi, mereka hanya mengunakan suara untuk menjalankan aplikasi tersebut.

Penelitian yang dilakukan oleh Khairunizam (2017) memanfaatkan Speech Recognition pada aplikasi musik untuk pencarian menggunakan pengucapan suara yang akan diproses menjadi sebuah perintah yang akan langsung memutarkan music dan dapat mengontrol musik diantaranya perintah sebelumnya, selanjutnya, berhenti, mainkan, dan keluar [11]. Selain itu penelitian yang dilakukan oleh Rahmantara (2018) memanfaatkan teknologi speech recognition sebagai media untuk user memberikan input dengan menebak nama surah yang telah diperdengarkan dengan menggunakan pengucapan suara sebagai pengganti inputan menggunakan keyboard [16]. Sedangkan menurut Supriyanta (2014) memanfaatkan fitur pada Android yakni API Google Speech yang bertujuan untuk membuat suara sebagai alternatif metode input sehingga mengurangi kelambatan dan rentan kesalahan memasukkan teks ke dalam perangkat mobile dibandingkan dengan mengetik pada keyboard [22].

Berdasarkan hasil dari penelitian sebelumnya maka mendorong penulis untuk membuat sebuah aplikasi kamus bahasa
Indonesia-Sumbawa berbasis Android memanfaatkan teknologi speech recognition.

\section{METODE PENELITIAN}

Metode penelitian yang digunakan dalam penyusunan tugas akhir ini adalah metode pengembangan Waterfall. Menurut Pressman (2002 : 37), waterfall adalah model yang mengusulkan sebuah pendekatan kepada pengembangan perangkat lunak yang sistematik dan sekuensial yang dimulai pada tingkat dan kemajuan sistem pada seluruh analisis, desain, kode, pengujian dan pemeliharaan.

A. Tahap Analisys

1) Analisis Sistem

Analisis sistem bertujuan untuk memperoleh informasi dan data mengenai sistem aplikasi yang memanfaatkan speech recognition dalam pengiriman pesan atau informasi yang mampu mengenali sebuah kata berbahasa indonesia yang diucapkan dan menerjemahkannya kedalam bahasa Sumbawa dalam format teks.

2) Analisis Kebutuhan

Analisis kebutuhan (requirement) aplikasi kamus bahasa Indonesia-Sumbawa terdapat dua tipe kebutuhan yaitu kebutuhan fungsional dan kebutuhan non fungsional. Secara umum, kebutuhan non fungsional suatu perangkat lunak terdiri dari empat macam yaitu usability (kemudahan penggunaan sistem), reliability (kehandalan sistem), portability (kemudahan dalam pengaksesan sistem termasuk perangkat lunak dan perangkat keras), dan supportability (dukungan dalam penggunaan sistem). Dari keempat kebutuhan non-fungsional tersebut, dalam aplikasi kamus bahasa IndonesiaSumbawa hanya akan membahas tentang portability meliputi perangkat lunak dan perangkat keras.

3) Teknik Pengumpulan Data

- Analisis Dokumen

Teknik yang digunakan dalam pengumpulan data dengan analisis dokumen yaitu mengumpulkan data-data yang berhubungan dengan obyek penelitian. Data pada Skripsi ini diperoleh melalui Kamus Sumbawa - Indonesia yang diterbitkan oleh Departemen Pendidikan Nasional Pusat Bahasa Provinsi Nusa Tenggara Barat pada tahun 2009. 
- Studi Literatur

Teknik yang digunakan dalam pengumpulan data dengan studi literatur yaitu dengan mempelajari artikel ilmiah yang membahas tentang speech recognition, seperti terlihat pada tabel $\mathrm{I}$.

TABEL I. ATRIKEL ILMIAH TENTANG SPEECH RECOGNITION

\begin{tabular}{|c|c|c|c|c|}
\hline $\begin{array}{l}\mathbf{N} \\
\mathbf{0}\end{array}$ & Penulis & $\begin{array}{c}\text { Tah } \\
\text { un }\end{array}$ & Judul & Pembahasan \\
\hline 1 & $\begin{array}{l}\text { Khairunizam } \\
\text { Danuri } \\
\text { Jaroji }\end{array}$ & $\begin{array}{l}201 \\
7\end{array}$ & $\begin{array}{ll}\text { Aplikasi Pemutar } & \text { Musik } \\
\text { Menggunakan } & \text { Speech } \\
\text { Recognition } & \end{array}$ & $\begin{array}{l}\text { Pemanfaatan Speech Recognition pada } \\
\text { aplikasi musik untuk pencarian } \\
\text { menggunakan pengucapan suara yang } \\
\text { akan diproses menjadi sebuah perintah } \\
\text { yang akan langsung } \\
\text { memutarkan music dan dapat } \\
\text { mengontrol musik diantaranya perintah } \\
\text { sebelumnya, selanjutnya, berhenti, } \\
\text { mainkan, dan keluar. }\end{array}$ \\
\hline 2 & $\begin{array}{l}\text { Dhimas Sena Rahmantara } \\
\text { Kartina Diah Kesuma } \\
\text { Wardhani } \\
\text { Maksum Ro'is Adin Saf }\end{array}$ & $\begin{array}{l}201 \\
8\end{array}$ & \begin{tabular}{lr}
\multicolumn{2}{l}{ Aplikasi Pengenalan Nama } \\
Surah pada Juz ke 30 Kitab \\
Suci & Al-Qur'an \\
Menggunakan & Speech \\
Recognition &
\end{tabular} & $\begin{array}{l}\text { Pemanfaatan teknologi speech } \\
\text { recognition sebagai media untuk user } \\
\text { memberikan input dengan menebak } \\
\text { nama surah yang telah diperdengarkan } \\
\text { dengan menggunakan pengucapan } \\
\text { suara. }\end{array}$ \\
\hline 3 & $\begin{array}{l}\text { Supriyanta } \\
\text { Pudji Widodo } \\
\text { Bekti Maryuni Susanto }\end{array}$ & $\begin{array}{l}201 \\
4\end{array}$ & $\begin{array}{l}\text { Aplikasi Konversi Suara } \\
\text { Ke Teks Berbasis Android } \\
\text { Menggunakan } \\
\text { Google Speech Api }\end{array}$ & $\begin{array}{l}\text { Pemanfaatan fitur pada Android yakni } \\
\text { API Google Speech yang bertujuan } \\
\text { untuk membuat suara sebagai alternatif } \\
\text { metode input sehingga mengurangi } \\
\text { kelambatan dan rentan kesalahan } \\
\text { Memasukkan teks ke dalam perangkat } \\
\text { mobile dibandingkan dengan mengetik } \\
\text { pada keyboard. }\end{array}$ \\
\hline
\end{tabular}

\section{B. Tahap Design \\ 1) Aktor}

Aplikasi kamus bahasa IndonesiaSumbawa ini memiliki satu aktor yaitu user atau pengguna. Pengguna adalah orang yang menjalankan aplikasi kamus bahasa IndonesiaSumbawa.

\section{2) Flowchart Sistem}

Penggunaan flowchart bertujuan untuk mengetahui proses-proses atau prosedur dari sebuah program sehingga memudahkan untuk memahami program yang akan dibangun.

Flowchart sistem dapat dijelaskan sebagai berikut :

1. Input suara, ucapkan kata yang ingin dicari.

2. kemudian klik icon google speech sebagai tempat proses untuk mendeteksi perintah suara yang diucapkan penguna.

3. Setelah suara terdeteksi google speech, maka suara yang terdeteksi dirubah oleh google speech menjadi teks. Teks tersebut kemudian dicocokan ke dalam database list kata dengan mengunakan fungsi like.

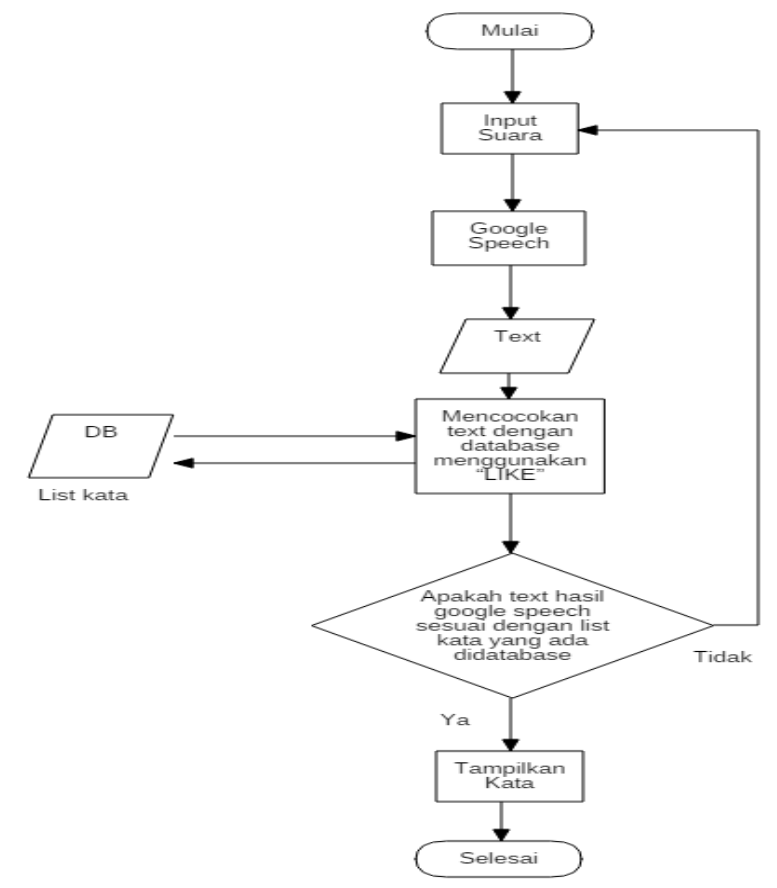




\section{Gambar. 1 Flowchart Sistem}

4. Setelah teks sesuai dengan database list kata, maka teks yang sudah cocok dengan kata tersebut akan ditampilkan sesuai dengan kata yang didapatkan dari database.

5. Apabila text tersebut tidak cocok dengan isi dalam database, maka kata tidak akan ditampilkan dan pengguna harus kembali lagi ke inputan suara.

\section{3) Use Case Diagram}

Use Case Diagram menjelasknan tentang fitur-fitur dan fungsionalitas yang tersedia dalam aplikasi kamus bahasa Indonesia-Sumbawa



Gambar. 2 Use case diagram kebutuhan fungsional

Berikut ini adalah penjelasan setiap use case pada Gambar 2. Penjelasan tersebut meliputi nama, kode use case, kebutuhan fungsional yang terkait dengan use case tersebut, deskripsi use case, dan kondisi sebelum (pre-condition) dan kondisi sesudah (post condition) proses tersebut dilakukan.

TABEL II. DESKRIPSI USE CASE CARI KATA

\begin{tabular}{|l|l|}
\hline \multicolumn{1}{|c|}{ Atribut } & \multicolumn{1}{c|}{ Keterangan } \\
\hline Nama & Cari kata \\
\hline Kode & UC-1 \\
\hline $\begin{array}{l}\text { Kebutuhan } \\
\text { Fungsional }\end{array}$ & F-1 \\
\hline Deskripsi & $\begin{array}{l}\text { Pengguna memasukan kata yang } \\
\text { diinginkan }\end{array}$ \\
\hline $\begin{array}{l}\text { Pre- } \\
\text { Condition }\end{array}$ & Pengguna telah membuka aplikasi \\
\hline $\begin{array}{l}\text { Post } \\
\text { Condition }\end{array}$ & $\begin{array}{l}\text { Jika kata tersedia dan cocok maka } \\
\text { kata akan ditampilkan }\end{array}$ \\
\hline
\end{tabular}

\section{TABEL III. DESKRIPSI USE CASE KELOLA} KATA FAVORIT

\begin{tabular}{|l|l|}
\hline \multicolumn{1}{|c|}{ Atribut } & \multicolumn{1}{c|}{ Keterangan } \\
\hline Nama & Kelola kata favorit \\
\hline Kode & UC-2 \\
\hline $\begin{array}{l}\text { Kebutuhan } \\
\text { Fungsional }\end{array}$ & F-2 \\
\hline Deskripsi & $\begin{array}{l}\text { Pengguna menambah, menghapus, } \\
\text { dan melihat daftar kata favorit }\end{array}$ \\
\hline Pre-Condition & Pengguna telah membuka aplikasi \\
\hline
\end{tabular}

\begin{tabular}{|l|l|}
\hline & dan melakukan use case UC-1 \\
\hline $\begin{array}{l}\text { Post } \\
\text { Condition }\end{array}$ & $\begin{array}{l}\text { Jika berhasil maka kata akan } \\
\text { ditampilkan atau dihilangkan dari } \\
\text { daftar kata favorit }\end{array}$ \\
\hline
\end{tabular}

TABEL IV. DESKRIPSI USE CASE KELOLA KATA BARU

\begin{tabular}{|l|l|}
\hline \multicolumn{1}{|c|}{ Atribut } & \multicolumn{1}{c|}{ Keterangan } \\
\hline Nama & Kelola kata baru \\
\hline Kode & UC-3 \\
\hline $\begin{array}{l}\text { Kebutuhan } \\
\text { Fungsional }\end{array}$ & F-3 \\
\hline Deskripsi & $\begin{array}{l}\text { Pengguna menambah, menghapus, } \\
\text { mengedit dan melihat daftar kata } \\
\text { baru }\end{array}$ \\
\hline Pre-Condition & Pengguna telah membuka aplikasi \\
\hline $\begin{array}{l}\text { Post } \\
\text { Condition }\end{array}$ & $\begin{array}{l}\text { Jika berhasil maka kata akan } \\
\text { ditampilkan atau dihilangkan dari } \\
\text { daftar kata baru }\end{array}$ \\
\hline
\end{tabular}

TABEL V. DESKRIPSI USE CASE LIHAT HISTORIS KATA

\begin{tabular}{|l|l|}
\hline \multicolumn{1}{|c|}{ Atribut } & \multicolumn{1}{c|}{ Keterangan } \\
\hline Nama & Lihat historis kata \\
\hline Kode & UC-4 \\
\hline $\begin{array}{l}\text { Kebutuhan } \\
\text { Fungsional }\end{array}$ & F-4 \\
\hline Deskripsi & $\begin{array}{l}\text { Pengguna melihat daftar kata yang } \\
\text { pernah diakses }\end{array}$ \\
\hline Pre-Condition & $\begin{array}{l}\text { Pengguna telah membuka aplikasi } \\
\text { dan melakukan use case UC-1 }\end{array}$ \\
\hline $\begin{array}{l}\text { Post } \\
\text { Condition }\end{array}$ & $\begin{array}{l}\text { Aplikasi menampilkan daftar kata } \\
\text { yang pernah diakses, dan diurutkan } \\
\text { berdasarkan waktu pengaksesan } \\
\text { dari atas ke bawah }\end{array}$ \\
\hline
\end{tabular}

TABEL VI. DESKRIPSI USE CASE LIHAT PETUNJUK

\begin{tabular}{|l|l|}
\hline \multicolumn{1}{|c|}{ Atribut } & \multicolumn{1}{c|}{ Keterangan } \\
\hline Nama & Lihat petunjuk \\
\hline Kode & UC-5 \\
\hline $\begin{array}{l}\text { Kebutuhan } \\
\text { Fungsional }\end{array}$ & F-5 \\
\hline Deskripsi & $\begin{array}{l}\text { Pengguna melihat petunjuk dalam } \\
\text { menggunakan aplikasi }\end{array}$ \\
\hline Pre-Condition & Pengguna telah membuka aplikasi \\
\hline $\begin{array}{l}\text { Post } \\
\text { Condition }\end{array}$ & $\begin{array}{l}\text { Aplikasi menampilkan daftar } \\
\text { informasi tentang petunjuk dalam } \\
\text { menggunakan aplikasi }\end{array}$ \\
\hline
\end{tabular}

TABEL VII. DESKRIPSI USE CASE LIHAT TENTANG

\begin{tabular}{|l|l|}
\hline \multicolumn{1}{|c|}{ Atribut } & \multicolumn{1}{c|}{ Keterangan } \\
\hline Nama & Lihat tentang \\
\hline Kode & UC-6 \\
\hline $\begin{array}{l}\text { Kebutuhan } \\
\text { Fungsional }\end{array}$ & F-6 \\
\hline
\end{tabular}




\begin{tabular}{|l|l|}
\hline Deskripsi & $\begin{array}{l}\text { Pengguna melihat informasi } \\
\text { tentang aplikasi dan penulis }\end{array}$ \\
\hline Pre-Condition & Pengguna telah membuka aplikasi \\
\hline $\begin{array}{l}\text { Post } \\
\text { Condition }\end{array}$ & $\begin{array}{l}\text { Aplikasi menampilkan informasi } \\
\text { tentang aplikasi dan penulis }\end{array}$ \\
\hline
\end{tabular}

4) Perancangan Basis Data

Aplikasi kamus bahasa IndonesiaSumbawa menggunakan database SQLite sebagai basis data untuk menyimpan daftar kata. Daftar kata tersebut disimpan dalam satu tabel dengan nama tabel adalah kamus yang memiliki atribut id, kata, arti, contoh, favorit, dan historis.

TABEL VIII. DESKRIPSI ATRIBUT TABEL KAMUS

\begin{tabular}{|l|l|l|}
\hline Atribut & Tipe Data & \multicolumn{1}{|c|}{ Keterangan } \\
\hline Id & Integer & $\begin{array}{l}\text { Primary key } \\
\text { Autoincrement }\end{array}$ \\
\hline Kata & Text & Menyimpan kata \\
\hline Arti & Text & Menyimpan arti kata \\
\hline Contoh & Text & $\begin{array}{l}\text { Menyimpan contoh } \\
\text { penggunaan kata dalam } \\
\text { bentuk kalimat }\end{array}$ \\
\hline Favorit & Integer & $\begin{array}{l}\text { Menyimpan nilai 0 dan 1 } \\
\text { sebagai parameter kata } \\
\text { yang digolongkan favorit } \\
\text { atau tidak dengan Nilai } \\
\text { default adalah 0, dan } \\
\text { nilai 1 sebagai parameter } \\
\text { kata digolongkan favorit }\end{array}$ \\
\hline Historis & Text & $\begin{array}{l}\text { Menyimpan waktu akses } \\
\text { kata }\end{array}$ \\
\hline kataBaru & Integer & $\begin{array}{l}\text { Menyimpan nilai 0 dan 1 } \\
\text { sebagai parameter kata } \\
\text { yang digolongkan kata } \\
\text { baru atau tidak dengan } \\
\text { Nilai defaul adalah 0, } \\
\text { dan nilai 1 sebagai } \\
\text { parameter } \\
\text { digolongkan kata baru }\end{array}$ \\
\hline
\end{tabular}

5) Perancangan Antarmuka

Adapun aplikasi yang dibangun terdiri dari beberapa halaman. Berikut merupakan perancangan halaman dari Aplikasi kamus bahasa Indonesia Sumbawa:

a. Perancangan halaman menu

Halaman menu pada aplikasi kamus bahasa Indonesia-Sumbawa akan menggunakan sliding navigation. Adapun desain antarmuka dari Halaman Menu adalah seperti pada Gbr. 3

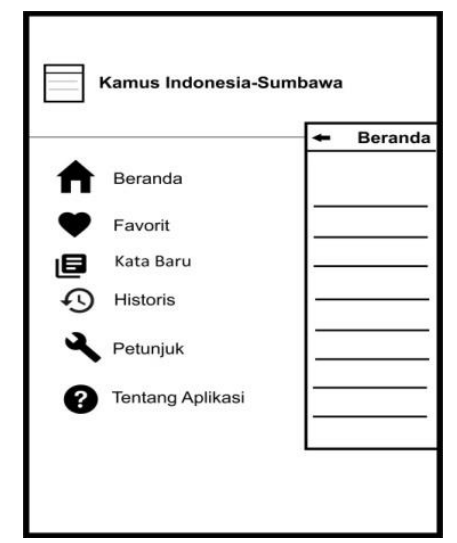

Gambar 3. Rancangan Layout Halaman Menu

\section{b. Beranda}

Beranda merupakan tampilan awal dari aplikasi kamus bahasa Indonesia-Sumbawa saat pertama kali dijalankan. Adapun desain antarmuka dari menu beranda adalah seperti pada Gambar 4.

\begin{tabular}{|l|}
\hline \multicolumn{2}{|l|}{ Beranda } \\
\hline \\
\hline Kata 1 \\
\hline Kata 2 \\
\hline Kata 3 \\
\hline Kata 4 \\
\hline Kata 5 \\
\hline
\end{tabular}

Gambar 4. Rancangan Layout Beranda

c. Favorit

Favorit digunakan untuk mengelola daftar kata favorit seperti menambah serta menghapus kata dari daftar favorit. Adapun desain antarmuka dari menu favorit adalah seperti pada Gbr. 5

\begin{tabular}{|l|}
\hline Favorit \\
\hline Kata 1 \\
\hline Kata 2 \\
\hline Kata 3 \\
\hline Kata 4 \\
\hline Kata 5 \\
\hline Kata 6 \\
\hline
\end{tabular}

Gambar 5. Rancangan Layout Favorit

d. Kata Baru 
Kata Baru digunakan untuk mengelola daftar kata baru seperti menambah, mengedit serta menghapus kata dari daftar kata baru. Adapun desain antarmuka dari menu kata baru adalah seperti pada Gbr. 6

\begin{tabular}{|l|}
\hline Kata Baru \\
\hline Kata 1 \\
\hline Kata 2 \\
\hline Kata 3 \\
\hline Kata 4 \\
\hline Kata 5 \\
\hline Kata 6 \\
\hline
\end{tabular}

Gambar 6. Rancangan Layout Kata Baru

\section{e. Historis}

Historis akan menampilkan daftar kata yang terakhir kali diakses. Adapun desain antarmuka dari menu historis adalah seperti pada Gambar 7.

\begin{tabular}{|l|}
\hline Historis \\
\hline Kata 1 \\
\hline Kata 2 \\
\hline Kata 3 \\
\hline Kata 4 \\
\hline Kata 5 \\
\hline Kata 6 \\
\hline
\end{tabular}

Gambar 7. Rancangan Layout Historis

\section{f. Petunjuk}

Petunjuk merupakan tampilan yang berisi informasi mengenai cara penggunaan aplikasi kamus bahasa Indonesia-Sumbawa. Adapun desain antarmuka dari menu petunjuk adalah seperti pada Gambar 8



Gambar 8. Rancangan Layout Petunjuk

\section{g. Tentang}

Tentang merupakan tampilan yang berisi informasi mengenai aplikasi dan penulis. Adapun desain antarmuka dari menu tentang adalah seperti pada Gambar 9



Gambar 9 Rancangan Layout Tentang

\section{HASIL DAN PEMBAHASAN}

A. Persiapan Implementasi

Pada tahapan ini dialakukan beberapa persiapan sebelum melakukan implementasi program. Adapun tahapan yang dilakukan dalam proses ini adalah sebagai berikut:

1) Instalasi JDK (Java Development Kit)

JDK merupakan software development environment yang berguna untuk mengembangkan aplikasi berbasis Java. JDK diperlukan disini karena dalam pembuatan program ini menggunakan bahasa pemrograman java.

2) Instalasi Android Studio

Instalasi Android studio sebagai IDE yang digunakan untuk membuat aplikasi android.

3) Instalasi DB Browser for SQLite

$D B$ Browser for SQLite (DB4S) adalah alat open source berkualitas tinggi, visual untuk membuat, mendesain, dan mengedit file database yang kompatibel dengan SQLite.

B. Tahap Pembangunan

Dalam pembangunan aplikasi ini, terdapat 2 (dua) tahapan yang lakukan. Adapun tahapan tersebut antara lain:

1) Pembuatan Database

Pembuatan database diimplementasi menggunakan aplikasi SQLite Browser. Adapun implementasi database menggunakan SQLite Browser ditunjukkan seperti pada Gambar 10 


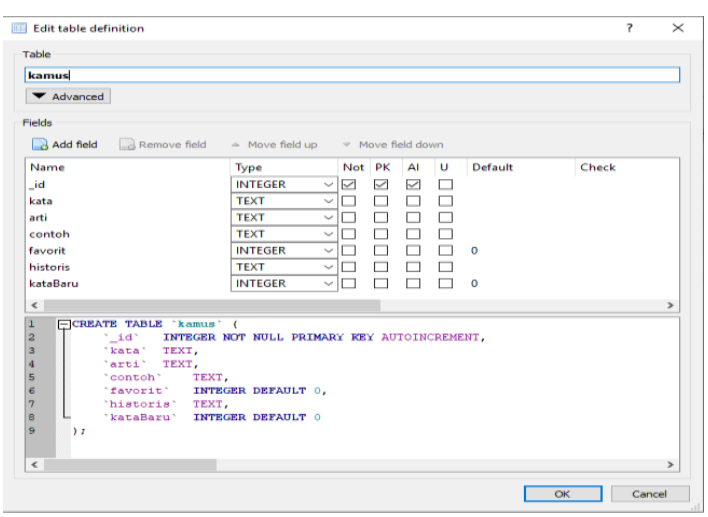

Gambar 10 Pembuatan Database Dengan Sqlite Browser

2) Pembuatan Program

Pembuatan program menggunakan bantuan IDE Android Studio 3.3.2. Program dibangun menggunakan bahasa pemrograman java. Android Studio dipilih karena merupakan IDE resmi yang dikeluarkan oleh Google pada tahun 2014 yang berbasiskan Intellij IDEA.

\section{Implementasi Speech Recognition}

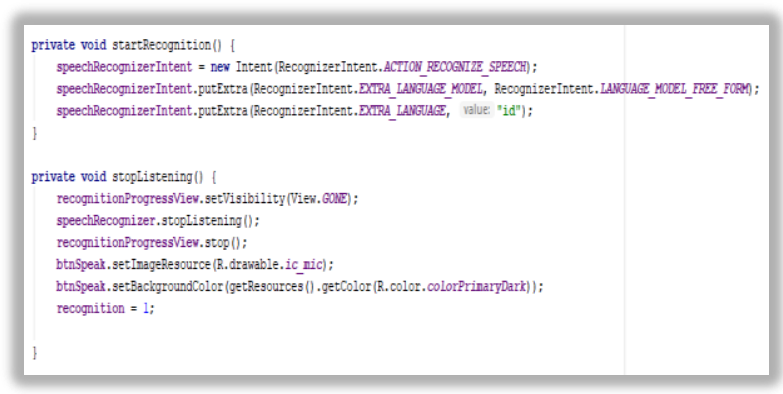

Gambar 11 Implementasi Speech Recognition Gambar 11 merupakan potongan kode untuk memanggil fungsi speech recognition, Google Speech API dipanggil menggunakan framework ACTION_RECOGNIZE_SPEECH. Framework ini diimplementasikan menggunakan metode onActivityResult(). Selanjutnya library ini akan menangkap ucapan melalui mic pada smartphone. Ucapan yang ditangkap akan dikirimkan ke server Google untuk diterjemahkan ke dalam teks. Hasil terjemahan dalam bentuk teks dikirimkan kembali ke smartphone, dalam hal ini dalam field masukkan kata pencarian.

D. Hasil Tampilan Antarmuka a. Sliding Navigation

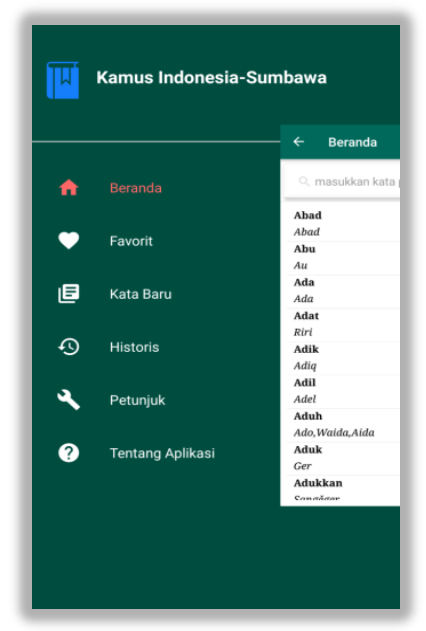

Gambar 12 Tampilan Sliding Navigation

Gambar 12 menunjukkan Pengguna dapat berpindah menu menggunakan Sliding navigation. Menu yang dimaksud meliputi menu beranda, favorit, historis,kata baru, petunjuk, dan tentang Aplikasi. Menu beranda merupakan menu default yang akan ditampilkan pertama kali saat aplikasi dijalankan.

b. Beranda

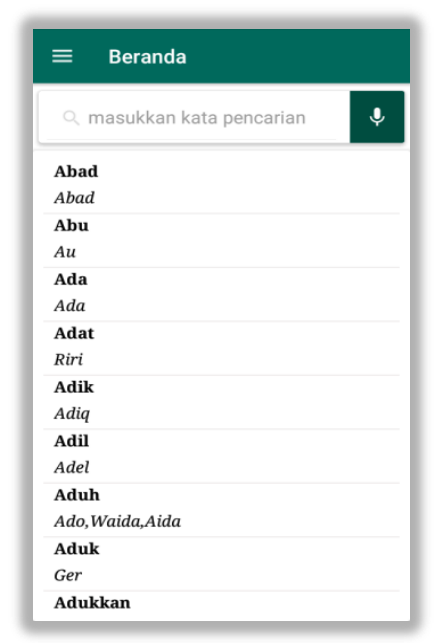

Gambar 13 Tampilan Menu Beranda

Gambar 13 menunjukkan menu awal saat aplikasi pertama kali dijalankan. Pada Menu ini, pengguna bisa melakukan pencarian kata baik berupa tulisan atau suara, melihat detil kata, dan berpindah ke menu lain dengan menggunakan Sliding navigation. 
c. Pencarian

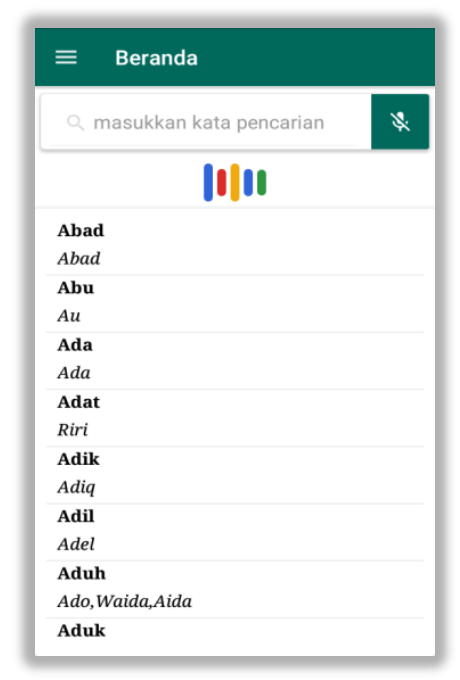

Gambar 14 Pencarian Dalam Menu Beranda

Gambar 14 menunjukkan fitur yang digunakan ketika pengguna berada pada menu beranda. Pengguna dapat melakukan pencarian kata dengan memasukkan kata yang diinginkan dengan cara mengetikkan atau mengucapkan kata. Selanjutnya, aplikasi akan melakukan pencocokan antara kata masukan pengguna dengan kata yang ada pada basis data. Aplikasi akan menampilkan kata dengan kata yang sama sebagai hasil.

d. Favorit

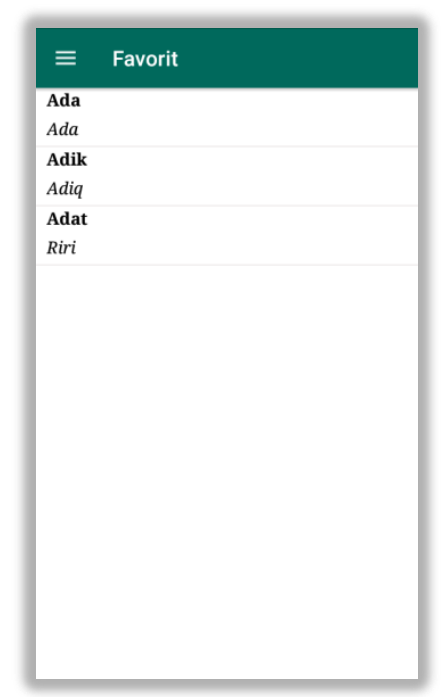

Gambar 15 Tampilan Menu Favorit

Gambar 15 menunjukkan menu untuk melihat daftar kata favorit,Pengguna bisa mengakses menu favorit. Pada menu ini, Pengguna juga bisa menambah atau menghapus daftar dari kata favorit namun terlebih dahulu pengguna harus berada pada detail kata. Jumlah maksimal kata dalam daftar kata favorit adalah 25 .

e. Kata Baru



Gambar 16 Tampilan Menu Kata Baru

Gambar 16 menunjukkan menu untuk melihat daftar kata baru,Pengguna bisa mengakses menu kata baru. Pada menu ini, Pengguna bisa menambah kata baru.

f. Historis

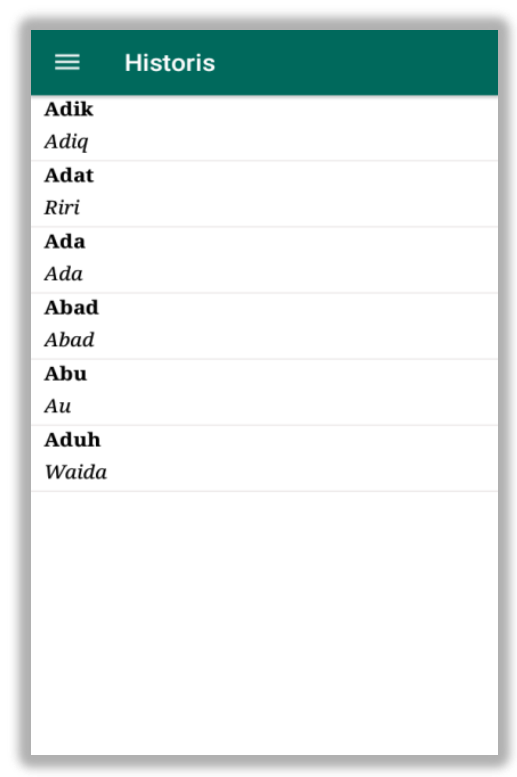

Gambar 17 Tampilan Menu Historis

Pada menu ini yang ditunjukkan pada Gambar 17, Pengguna dapat melihat daftar kata yang pernah diakses. Ketika pengguna melihat detil kata secara otomatis Kata akan disimpan 
dalam daftar historis. Jumlah maksimal kata dalam daftar historis adalah 25 .

\section{g. Petunjuk}

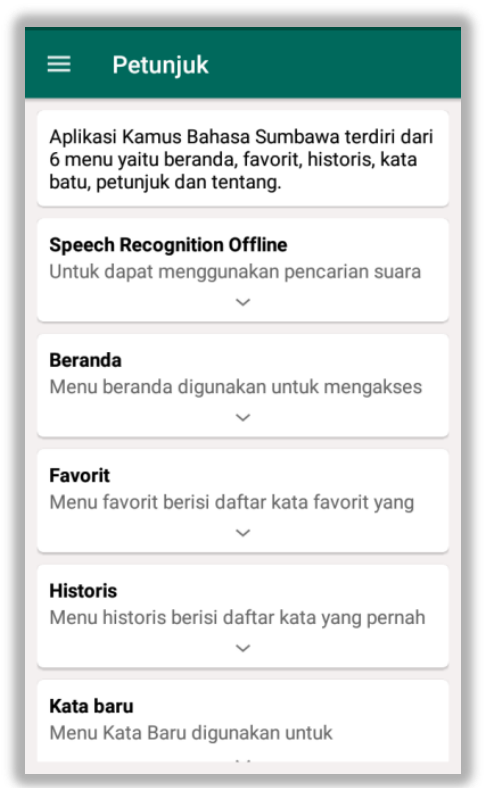

Gambar 18 Tampilan Menu Petunjuk

Gambar 18 menunjukkan menu yang berisi informasi mengenai cara penggunaan dan fitur yang terdapat dalam aplikasi, yaitu beranda, favorit, historis, petunjuk, kata baru dan tentang aplikasi.

\section{h. Tentang Aplikasi}

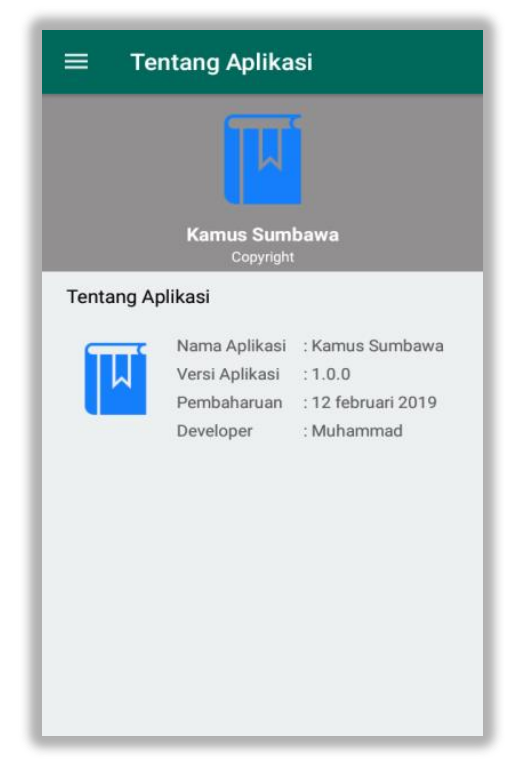

Gambar 19 Tampilan Menu Tentang Aplikasi

Gambar 19 menunjukkan Menu yang berisi informasi tentang aplikasi dan informasi mengenai penulis.

\section{E. Tahap Pengujian}

Setelah dilakukan rancangan maka berikut adalah hasil dari pengujiannya, pengujian sistem yang digunakan adalah pengujian Google Speech API, pengujian fungsi sistem dan pengujian sistem dengan kata :

\section{Pengujian Google Speech API}

Pada tahap uji google speech API dilakukan untuk menganalisa tahapan pengenalan suara berhasil atau tidak.

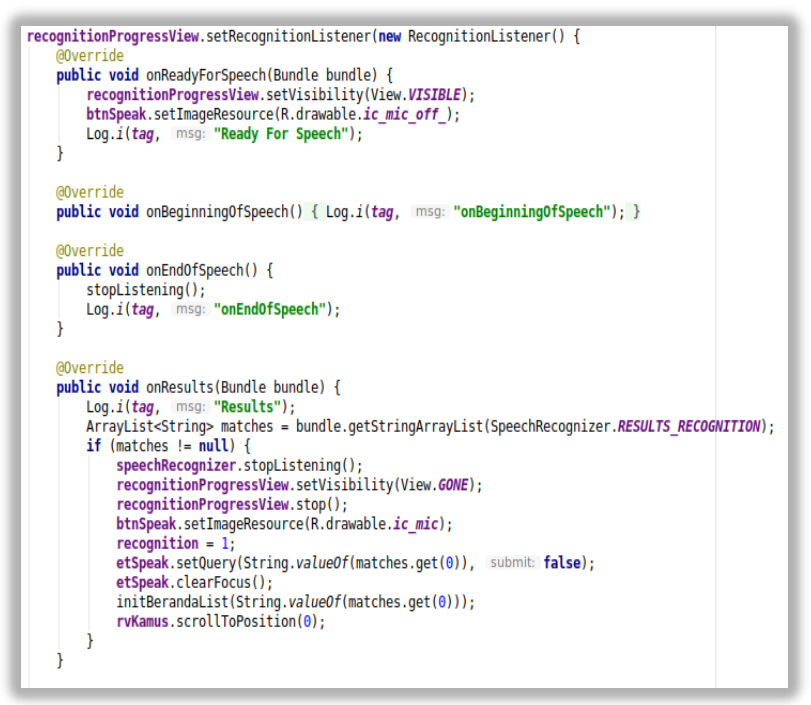

Gambar 20 Tampilan Uji Coba Google Speech API

Gambar 20 merupakan potongan kode untuk menguji tahapan google speech API ketika fungsi speech recognition dipanggil berhasil atau tidak dalam memproses suara yang diucapkan oleh pengguna.

Dimana metode onReadyForSpeech() dipanggil ketika endpointer siap bagi pengguna untuk mulai berbicara, metode onBeginningSpeech() dijalankan ketika pengguna sudah mulai berbicara, metode onEndOfSpeech() dipanggil setelah pengguna berhenti berbicara, sedangkan metode onResult() dipangil ketika hasil pengenalan suara berhasil atau siap.



Gambar 21 Tampilan Uji Coba Google Speech API Gagal 
Gambar 21 merupakan hasil uji coba google speech API yang tidak berhasil dalam melakukan proses pengenalan suara yang telah diucapkan oleh pengguna. Gbr. 21 menunjukkan sistem tidak berhasil melakukan pengenalan suara ketika pengguna telah berhenti berbicara.

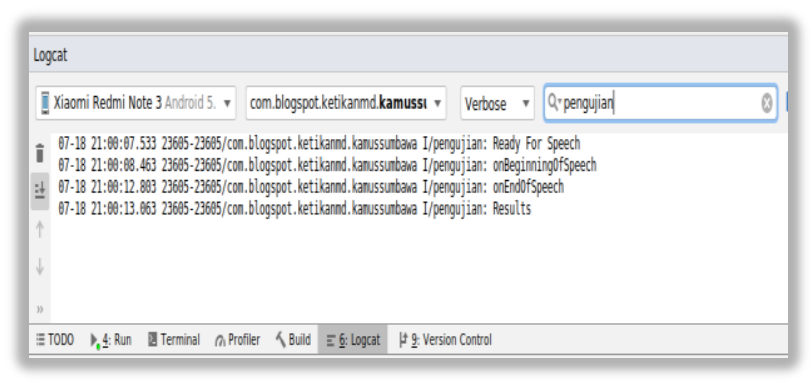

Gambar 22 Tampilan Uji Coba Google Speech API Berhasil

Gambar 22 merupakan hasil uji coba google speech API telah sukses dalam melakukan proses pengenalan suara yang telah diucapkan oleh pengguna. Gbr. 22 menunjukkan keluaran berupa pesan Result yang membuktikan sistem berhasil melakukan pengenalan suara ketika pengguna telah berhenti berbicara.

\section{Pengujian Metode Black Box Testing}

Berikut ini merupakan hasil uji coba terhadap fitur - fitur yang tersedia dalam aplikasi ini.

TABEL IX.HASIL UJI COBA BLACK BOX

\begin{tabular}{|c|l|l|l|}
\hline No & $\begin{array}{c}\text { Skenario } \\
\text { Pengujian }\end{array}$ & $\begin{array}{l}\text { Hasil yang } \\
\text { DIharapkan }\end{array}$ & Keterangan \\
\hline 1 & $\begin{array}{l}\text { Menekan } \\
\text { menu } \\
\text { Beranda }\end{array}$ & $\begin{array}{l}\text { Sistem akan } \\
\text { menampilka } \\
\text { n daftar kata } \\
\text { pada } \\
\text { halaman } \\
\text { beranda }\end{array}$ & Valid \\
\hline 2 & $\begin{array}{l}\text { Memekan } \\
\text { pada } \\
\text { halaman } \\
\text { beranda. }\end{array}$ & $\begin{array}{l}\text { Sistem akan } \\
\text { menampilka } \\
\text { n pesan } \\
\text { untuk } \\
\text { mengucapka } \\
\text { n kata } \\
\text { pencarian }\end{array}$ & \\
\hline 3 & $\begin{array}{l}\text { Menekan } \\
\text { menu } \\
\text { Favorit }\end{array}$ & $\begin{array}{l}\text { Sistem akan } \\
\text { menampilka } \\
\text { ndaftar kata } \\
\text { pada } \\
\text { halaman }\end{array}$ & Valid \\
\hline
\end{tabular}

\begin{tabular}{|c|c|c|c|}
\hline & & favorit & \\
\hline 4 & $\begin{array}{l}\text { Menekan } \\
\text { menu } \\
\text { Historis }\end{array}$ & $\begin{array}{l}\text { Sistem akan } \\
\text { menampilka } \\
\text { n daftar kata } \\
\text { pada } \\
\text { halaman } \\
\text { favorit }\end{array}$ & Valid \\
\hline 5 & $\begin{array}{l}\text { Menekan } \\
\text { menu } \\
\text { Petunjuk }\end{array}$ & $\begin{array}{l}\text { Sistem akan } \\
\text { menampilka } \\
\mathrm{n} \text { halaman } \\
\text { petunjuk }\end{array}$ & Valid \\
\hline 6 & $\begin{array}{l}\text { Menekan } \\
\text { menu } \\
\text { Tentang }\end{array}$ & $\begin{array}{l}\text { Sistem akan } \\
\text { menampilka } \\
\mathrm{n} \text { halaman } \\
\text { tentang }\end{array}$ & Valid \\
\hline 7 & $\begin{array}{l}\text { Menekan } \\
\text { tombol } \\
\text { favorit pada } \\
\text { halaman } \\
\text { detail kata }\end{array}$ & $\begin{array}{l}\text { Sistem dapat } \\
\text { melakukan } \\
\text { proses } \\
\text { tambah kata } \\
\text { ke favorit }\end{array}$ & Valid \\
\hline 8 & $\begin{array}{l}\text { Menekan } \\
\text { tombol } \\
\text { favorit pada } \\
\text { halaman } \\
\text { detail kata }\end{array}$ & $\begin{array}{l}\text { Sistem dapat } \\
\text { melakukan } \\
\text { proses hapus } \\
\text { kata dari } \\
\text { favorit }\end{array}$ & Valid \\
\hline 9 & $\begin{array}{l}\text { Sistem dapat } \\
\text { melakukan } \\
\text { proses } \\
\text { pencarian } \\
\text { kata pada } \\
\text { kolom } \\
\text { pencarian. }\end{array}$ & $\begin{array}{l}\text { Sistem } \\
\text { menampilka } \\
\text { n daftar kata } \\
\text { sesuai } \\
\text { pencarian }\end{array}$ & Valid \\
\hline 10 & $\begin{array}{l}\text { Menekan } \\
\text { salah satu } \\
\text { kata yang } \\
\text { ada pada } \\
\text { daftar kata }\end{array}$ & $\begin{array}{l}\text { Sistem akan } \\
\text { membuka } \\
\text { halaman } \\
\text { baru dan } \\
\text { menampilka } \\
\text { n detail kata }\end{array}$ & Valid \\
\hline 11 & $\begin{array}{l}\text { Menekan } \\
\text { tombol menu }\end{array}$ & $\begin{array}{l}\text { Sistem akan } \\
\text { menampilka } \\
\text { n daftar } \\
\text { menu }\end{array}$ & Valid \\
\hline
\end{tabular}

melakukan uji coba terhadap fungsionalitas setiap fitur. Selain itu, pengujian juga dilakukan dengan menguji setiap tombol yang ada, apakah aksinya sesui dengan yang dibutuhkan atau tidak. Berdasarkan tabel IX, semua fitur yang ada dalam aplikasi ini berfungsi dengan baik. 
3. Pengujian Pengenalan Suara

Pada tahap uji pengenalan suara dilakukan dengan pengujian sistem dengan kata. Berikut merupakan hasil uji sistem dengan kata:

\section{TABEL X. PENGUJIAN SISTEM DENGAN KATA}

\begin{tabular}{|c|c|c|c|c|c|}
\hline \multirow[b]{2}{*}{ No } & \multirow[b]{2}{*}{$\begin{array}{c}\text { Kata } \\
\text { Masukan }\end{array}$} & \multicolumn{2}{|c|}{$\begin{array}{c}\text { Sistem saat } \\
\text { Offline }\end{array}$} & \multicolumn{2}{|c|}{$\begin{array}{l}\text { Sistem saat } \\
\text { Online }\end{array}$} \\
\hline & & $\begin{array}{l}\text { Sesua } \\
\quad \mathrm{i}\end{array}$ & $\begin{array}{l}\text { Tidak } \\
\text { Sesuai }\end{array}$ & $\begin{array}{l}\text { Sesua } \\
\text { i }\end{array}$ & $\begin{array}{c}\text { Tidak } \\
\text { Sesua } \\
\text { i }\end{array}$ \\
\hline 1 & $\mathrm{Aku}$ & 10 & 0 & 10 & 0 \\
\hline 2 & Kuasa & 6 & 4 & 7 & 3 \\
\hline 3 & Lelah & 8 & 2 & 10 & 0 \\
\hline 4 & Mati & 8 & 2 & 9 & 1 \\
\hline 5 & Tidak & 10 & 0 & 10 & 0 \\
\hline 6 & Di mana & 10 & 0 & 10 & 0 \\
\hline 7 & Makan & 10 & 0 & 10 & 0 \\
\hline 8 & Minum & 10 & 0 & 10 & 0 \\
\hline 9 & Enak & 10 & 0 & 10 & 0 \\
\hline 10 & Bapak & 8 & 2 & 10 & 0 \\
\hline 11 & Ibu & 10 & 0 & 10 & 0 \\
\hline 12 & Adik & 10 & 0 & 10 & 0 \\
\hline 13 & Tidur & 10 & 0 & 10 & 0 \\
\hline 14 & Nama & 10 & 0 & 10 & 0 \\
\hline 15 & Jalan & 10 & 0 & 10 & 0 \\
\hline 16 & Celana & 10 & 0 & 10 & 0 \\
\hline 17 & Sebentar & 10 & 0 & 10 & 0 \\
\hline 18 & Besok & 10 & 0 & 10 & 0 \\
\hline 19 & Kalung & 8 & 2 & 9 & 1 \\
\hline 20 & Sekolah & 10 & 0 & 10 & 0 \\
\hline 21 & Hampir & 7 & 3 & 9 & 1 \\
\hline 22 & Uang & 10 & 0 & 10 & 0 \\
\hline 23 & Dada & 8 & 2 & 7 & 3 \\
\hline 24 & Air & 10 & 0 & 10 & 0 \\
\hline 25 & Tabrak & 10 & 0 & 10 & 0 \\
\hline 26 & Tolong & 9 & 1 & 10 & 0 \\
\hline 27 & Anda & 10 & 0 & 10 & 0 \\
\hline 28 & Belakang & 10 & 0 & 10 & 0 \\
\hline 29 & Gosok & 8 & 2 & 9 & 1 \\
\hline 30 & Topi & 8 & 2 & 6 & 4 \\
\hline \multicolumn{2}{|c|}{$\begin{array}{c}\text { Hasil } \\
\text { (persentase) }\end{array}$} & \multicolumn{2}{|c|}{$\begin{aligned} & 300 \\
= & 92.67 \%\end{aligned}$} & \multicolumn{2}{|c|}{$\begin{aligned} & 300 \\
= & 95.33 \%\end{aligned}$} \\
\hline
\end{tabular}

tabel $\mathrm{X}$ merupakan tabel ujicoba sistem menggunakan 30 kata yang berbeda dan setiap kata diulang sebanyak 10 kali sehingga di peroleh kecocokan antara kata masukan dan kata keluaran dengan persentase akurasi sistem ketika offline sebesar $92.67 \%$ dan akurasi sistem ketika online sebesar 95.33\%. Banyak faktor yang mempengaruhi akurasi sistem ini diantaranya intonasi suara dan kebisingan (noise).

\section{KESIMPULAN}

Berdasarkan hasil penelitian dan pembahasan yang telah dilakukan, penulis mengambil kesimpulan bahwa:

1. Telah dibangun Aplikasi kamus bahasa Indonesia-Sumbawa yang dapat bekerja dengan memanfaatkan suara sebagai inputan yang akan diproses sehingga user tidak perlu mengetikkan kata yang akan dicari.

2. Aplikasi kamus bahasa IndonesiaSumbawa ini dapat membantu pengguna dalam menerjemahkan Bahasa Indonesia ke Bahasa Sumbawa.

3. Dalam sistem pengenalan suara, banyak faktor yang mempengaruhi akurasi diantaranya intonasi suara dan kebisingan (noise).

4. Aplikasi dapat berjalan dengan atau tanpa koneksi internet.

5. Implementasi Google Speech API dilakukan dengan memanggil fungsi ACTION_RECOGNIZE_SPEECH.

Hasil akan dikembalikan melalui hasil aktivitas di onActivityResult(). Ucapan yang ditangkap melalui mic pada smartphone akan dikirimkan ke server Google untuk diterjemahkan ke dalam teks.

6. Setelah dilakukan uji coba dengan menggunakan 30 kata yang berbeda dan setiap kata diulang sebanyak 10 kali didapatkan hasil output dengan persentase sistem ketika offline sebesar 92.67\% dan sistem ketika online sebesar $95.33 \%$.

\section{SARAN}

Berdasarkan hasil dari pembuatan skripsi ini, maka peneliti menyarankan beberapa hal yang berguna dalam pengembangan sistem ini antara lain:

1. Dikembangkan ke dalam bahasa lain, terutama bahasa internasionall yang diakui PBB.

2. Kedepannya pada sistem ini bukan hanya dapat merubah suatu speech ke teks dan menterjemahkannya kedalam teks, namun hasil terjemahan dapat kita dengar tidak hanya sebatas teks yang terlihat. 


\section{REFERENSI}

[1] A.S. Rosa dan M. Shalahuddin. (2014). Rekayasa Perangkat Lunak Terstruktur dan Berorientasi Objek. Bandung:Informatika Bandung.

[2] Andi, J. (2015). Pembangunan Aplikasi Child Tracker Berbasis Assisted - Global Positioning System ( A-Gps ) Dengan Platform Android Jurnal Ilmiah Komputer dan Informatika ( KOMPUTA ). Jurnal Ilmiah Komputer Dan Informatika (KOMPUTA), 1(1), 1-8. Retrieved from

elib.unikom.ac.id/download.php?id=300375

[3] Andriani, S. (2016). Aplikasi Akademik Online Berbasis Mobile Android. Jurnal Sains Dan Teknologi Utama, Volume XI, Nomor 1, April 2016, XI(152).

[4] Barri, M. W. H., Lumenta, A. S. M., Wowor, A., \& Elektro-ft, J. T. (2015). Perancangan Aplikasi SMS GATEWAY Untuk Pembuatan Kartu Perpustakaan di Fakultas Teknik Unsrat, 23-28.

[5] Developers, android.speech. From https://developer.android.com/reference/android/ speech/package-summary.html. Diakses pada 17 Februari 2019

[6] Fathurrahman. (2016). Pengenalan dan jenisjenis data storage pada android. From https://www.okedroid.com/2016/04/pengenalandan-jenis-jenis-data-storage-pada-android.html. Diakses pada 5 April 2019

[7] Gunawan, C. A. dan J. Kasih. (2016). Aplikasi Android Online untuk berbagai Jenis Toko di Area Kota Bandung, 2, 331-340.

[8] Hidayat, S. (2018). Rancang Bangun Portal Seminar Nasional, (October).

[9] Iizuka, S., Tsujino, K., Oguri, S., \& Furukawa, H. (2012). Speech Recognition Technology and Applications for Improving Terminal Functionality and Service Usability. NTT DOCOMO Technical Journal Vol. 13 No. 4 , 7984.

[10] Kaur, Parneet, Preeti, saini. (2013). "Automoatic Speech Recognition: A Review".CSE Department, Kurukshetra University.

[11] Khairunizam, Danuri, Jaroji. (2017). Aplikasi Pemutar Musik Menggunakan Speech Recognition. Vol.2, No.2, Jurnal Inovtek Polbeng - Seri Informatika ISSN: 2527-9866.

[12] Mahsun. (1997). Kekerabatan Bahasa-Bahasa di Nusa Tenggara Barat: Kajian Tanah Asal Penutur-Penuturnya. Disampaikan dalam Rangka Bulan Apresiasi Budaya IV NTB, di Mataram 21-24 Juli 1997.

[13] Mahsun, dkk. ( 2009). "Kamus Sumbawa Indonesia". Mataram: Departemen Pendidikan Nasional Pusat Bahasa Kantor Bahasa Provinsi Nusa Tenggara Barat.
[14] McCowan,I. ,Moore,D., Dines,J., GaticaPerez,D., Flynn,M.,Wellner,P.,dan Bourlard,H. (2005). On the Use of Information Retrieval Measures for Speech Recognition Evaluation ,Laporan Penelitian IDIAP-RR 0473.

[15] Pressman, Roger. (2002). Rekayasa Perangkat Lunak: Pendekatan Praktis. Yogyakarta: Andi.

[16]Rahmantara, D. S., Wardhani, K. D. K., Saf, M. R. A. (2018). Aplikasi Pengenalan Nama Surah pada Juz ke 30 Kitab Suci Al-Qur'an Menggunakan Speech Recognition. Vol.2, No.1, Jurnal Resti ISSN: 2580-0760, 345 - 353.

[17] Rahmattulah S. (2015). Rancang Bangun Kamus Besar Bahasa Daerah Sumbawa Berbasis Android Dengan Algoritma Caverphone. Skripsi. Malang: Universitas Muhammadiyah Malang.

[18] Reddy, R. B., \& Mahender, E. (2013). Speech To Text Conversion Using Android Paltform. Internaitonal Journal of Engineering Research and Applicaiton (IJERA) Vol. 3 No.1 , 253-258.

[19] Rouse, Margareth. (2007) Speech Recognition. From

https://searchcustomerexperience.techtarget.com/ definition/speech-recognition. Diakses pada 6 April ,2019

[20] Sofya, N. D. , dkk. (2017). Rancang bangun aplikasi kamus bahasa sumbawa berbasis android.Vol.17, No.1, Jurnal Matrik eISSN:2476-9843.

[21] Subrata, G. (2009). Kajian Ilmu Perpustakaan: Literatur Primer, Sekunder Dan Tersier.http://library.um.ac.id/images/stories/pust akawan/kargto/Kajian\%20Ilmu\%20Perpustakaan Literatur\%20Pimer\%20Sekunder\%20dan\%20T ersier.pdf. Diakses pada 12 Maret 2019.

[22] Supriyanta, Widodo, P., Susanto, B. M. (2014). Aplikasi Konversi Suara Ke Teks Berbasis Android Menggunakan Google Speech Api. Vol.2, No.2, Bianglala Informatika. 